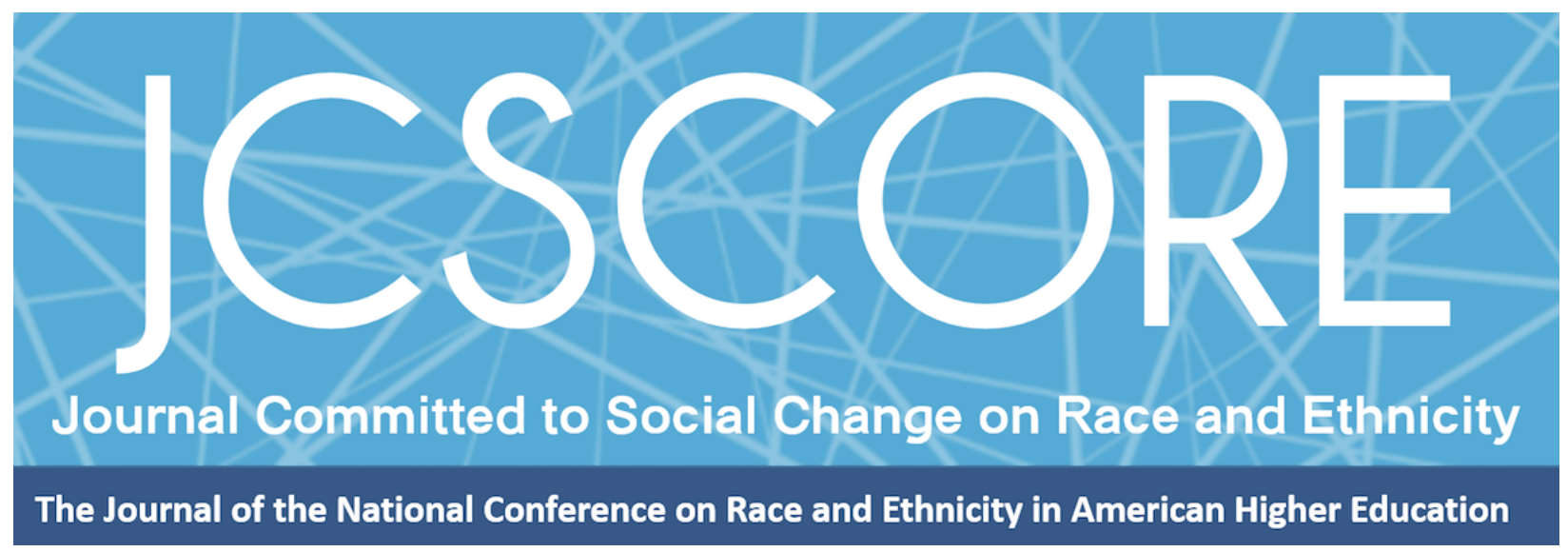

\title{
ADDRESSING ANTI-BLACK RACISM IN HIGHER EDUCATION: LOVE LETTERS TO BLACKNESS AND RECOMMENDATIONS TO THOSE WHO SAY THEY LOVE US
}

\author{
Cameron C. Beatty \\ Florida State University \\ Tenisha Tevis \\ Oregon State University \\ Lorraine Acker \\ SUNY Brockport \\ Reginald Blockett \\ Grand Valley State University \\ Eugene Parker \\ University of Kansas
}

Journal Committed to Social Change on Race and Ethnicity

Volume 6, Issue $1 \mid 2020$

Copyright and Open Access

(C) 2020 Cameron C. Beatty, Tenisha Tevis, Lorraine Acker, Reginal Blockett, \& Eugene Parker (c) $\underset{\mathrm{EY} \text { (i) }}{\mathrm{NGA}}$

This work is licensed under a Creative Commons Attribution-NonCommercial-ShareAlike 4.0 International License. Permission of the authors is required for distribution and for all derivative works, including compilations and translations. Quoting small sections of text is allowed as long as there is appropriate attribution and the article is used for non-commercial purposes.

The Journal Committed to Social Change on Race and Ethnicity (ISSN 2642-2387) is published by the National Conference on Race and Ethnicity (NCORE), a production of the University of Oklahoma, in partnership with the University of Oklahoma Libraries. 


\title{
Addressing Anti-Black Racism in Higher Education: Love Letters to Blackness and Recommendations to Those Who Say They Love Us
}

\author{
Cameron C. Beatty \\ Florida State University \\ Tenisha Tevis \\ Oregon State University \\ Lorraine Acker \\ SUNY Brockport \\ Reginald Blockett \\ Grand Valley State University \\ Eugene Parker \\ University of Kansas
}

For this issue, the letter from the editor comes from a few of the Black members

of the editorial board ${ }^{1}$. We write this love letter to Black students, faculty, staff, executive leadership in higher education, and the surrounding community to center their/our

Blackness. We want to acknowledge your frustration and anxiety. As Stewart (2020) so

eloquently stated, we come from a place of pain and rage.

Yet, if pain and sadness were instrumental, perhaps it is for reminding me that I am human. That I am not made of walls. That I am flesh and blood and bones. That I am not all hard edges and blunt force. Perhaps this is what Rustin meant when he told us not to be destroyed by injustice. I must not give up my claim to be fully human, to hold my rage and my pain together in my heart. (para. 25)

The "Dear" sections of this letter are written in raw language, specifically to Black people - acknowledging that it is ok to be pissed, fatigued, and not wanting to engage in

\footnotetext{
${ }^{1}$ We were invited by JCSCORE's Editor-in-Chief Cristobal Salinas Jr. to write this letter from the Editorial Board Members with the goal "to center and amplify Blackness in academia". We thank you for this invitation, and for creating a space for us in JCSCORE.
} 
Journal Committed to Social Change on Race and Ethnicity | Volume 6, Issue 1 | 2020

performative anti-racist expressions of love for Black people. We do not want you to dismiss your own racial battle fatigue you have been coping with this summer. We hope through this letter you consider centering and recentering your wellness through this pandemic and the recent performative gestures of love for Blackness in academe.

We write this letter in five parts for the purpose of acknowledging Blackness in higher education in a real and intentional way. We also want to distinguish the unique lived experiences of navigating anti-Black racism in higher education, across roles and responsibilities. We recognize that Blackness is not a monolithic experience and we also acknowledge that each lived experience with racism cannot be captured in this letter. Nevertheless, we hope that as Black people we continue to consider ways of being intentional in acknowledging who we are as we do through our use of language. References to being African American, pan-African, and Black, Indigenous, People of Color (BIPOC), demonstrate to how multifaceted we are and the ways in which we matter. Grady (2020) points out that an in-group will develop a new label for itself as a way of talking about the experiences' members of that group share. Furthermore, Grady (2020) emphasizes that white people begin using language in a broad and unspecific way, robbing it of its political power:

Often, it's rooted in a desire to be seen as "not racist" or, more broadly, as one of "the good guys." Anxious and indiscriminate and mostly white liberal speakers vaguely grasp that old terms like "African American," "minority," and "diverse" are outdated, and that new terms like "People of Color" and "BIPOC" are in. And so they begin to slot in the new terms for the old without thinking too much about how the new terms are different. (para. 6)

Grady highlights that while people may not intend harm when they misuse our language, their intentions are still harmful. For many activists and scholars, this is manifested when others want to disingenuously address, for example, police brutality 
Journal Committed to Social Change on Race and Ethnicity | Volume 6, Issue 1 | 2020

against People of Color, when we know that police brutality disproportionately targets Black people. So for the purpose of these letters we are addressing how you/we matter, referring to the collective of Black people; with a capital 'B'!

Finally, to those who say they love us, those non-Black colleagues and peers who say "Black Lives Matter"; we hope the actionable recommendations we offer will support you in showing that love to Black students, faculty, staff, administrators, and the community. We acknowledge that whiteness only knows itself through Blackness, through the presence and maltreatment of Black people. If you say "I am anti-racist", then we ask you to reflect on the following questions:

- How are you addressing anti-Black racism in higher education?

- What campus policies and practices need to be eradicated because they disproportionately impact Black people?

- What role do you play in perpetuating anti-Black ideologies in higher education? We hope these questions and the actionable recommendations, offered throughout this letter, might be starting points and continuations for people doing and wanting to engage in this lifelong work of being anti-racist and supporting Black people in higher education.

\section{Dear Black Students,}

You matter! Your very existence matters! Your presence on college campuses matters! As you prepare to return to your college campuses, we wanted to remind you that you are seen, you are valued, you belong, and you are "Rooted" (Acker, 2017, p. 150). We acknowledge your justifiable rage as you navigate the spaces within the ivory tower that attempts to render you silent. Remember, that your greatness has no 
Journal Committed to Social Change on Race and Ethnicity | Volume 6, Issue 1 | 2020

bounds, so continue to be unapologetically Black - creative, innovative, influential, and fortunately/unfortunately resilient - some of you having overcome struggle and adversity. Know that you are more than a prop or a diversity quota, you are strong, you are confident, you are the making of a legacy. We see you standing on the frontlines as Black collegians who have come before you, disrupting inequities within the academy (Douglas et al., 2020), using your voice to advocate for change and inclusion; and this academic year will be no different. Some of you will serve on committees and task forces, some of you will question inequitable policies and practices, and others will join forces with prominent movements. In either case, while this work can have unintended consequences (Linder et al., 2019), please understand your efforts will not be in vein; your campus will be that much better because you stepped up.

Please know the Black higher education community is proud of the steps you are taking towards your educational goals and will continue to support you as you navigate the unrelenting trauma of anti-Blackness, tokenism, and white supremacy. We have heard your cries for help - cries that are the result of the daily microaggressions, worries about belonging (Brady et al., 2020; Hurtado et al., 2015; Stewart, 2019; Strayhorn, 2012), feelings of isolation and alienation, and because you have been made to feel like an insider-outsider (Collins, 1986). Though as card-carrying members of your college you may at times find yourself on the margin, be encouraged that you possess the strength and determinations of your ancestors. Again, we are proud of you.

Because college should be a time for you to thrive, discover your passions, both academically and personally, and to develop critical thinking skills that empower you to question systemic inequities and develop innovative solutions that will change our 
Journal Committed to Social Change on Race and Ethnicity | Volume 6, Issue 1 | 2020

world, we want to offer you tangible recommendations to help you in your endeavors. First, know that you are not in this fight alone; Black faculty, staff, administrators, and the community fight with you and on your behalf. Whether you are engaged in activism or are enduring in other ways, we encourage you to be part of healthy and uplifting communities of like-minded individuals both for studying and social activities. If possible, stay connected to family and friends from 'back home' as a means of self-care and love. Find a mentor to interact with regularly who will help guide you through your college journey, and perhaps beyond. We recommend that you reach out to one another. Black students can be siloed on college campuses because of their major, athletics, and/or social activities. Avail yourselves to one another to strengthen your efforts and your community. Work with allies, in this instance, trusted non-Black peers who are vested not only in your fight for justice, but also in your psychological wellbeing. Lastly, we strongly encourage you to prioritize your mental health. Look into the counseling and psychological services your campus offers. If this service is not available, then make a request to your institution's administration and build a coalition to hold them accountable.

The road ahead, paved with uncertainty, will not be easy but stay the course. Stay focused and committed to your goals, your purpose, and your intent to make higher education a more welcoming place for all. Your presence and contributions to the Black college experience will help inspire the next generation of Black collegians, including those who take up the mantle of leadership. Believe us, you are an inspiration. Remember, the problems of anti-Blackness and white supremacy on college campuses will not be solved in a semester nor during the time it takes to complete your degree(s). 
Journal Committed to Social Change on Race and Ethnicity | Volume 6, Issue 1 | 2020

Yet, your tenacity and will to not only survive, but to thrive, will model determination and ensure the success of those who come after you.

\section{Dear Black Faculty,}

You matter! As Black faculty, you bear the labor of our institution's academic mission of preparing students for a global political economy and advancing knowledge production and dissemination. Sadly, many of our institutional missions do not pause when you experience the constant compounded racial realities of being Black and professors/instructors. You are often expected to put your emotions to the side and objectively facilitate classroom discussions, conduct research and scholarship, and serve at the leisure of the academy by any means (Patton, 2018). However, in this moment marked by protest, unrest, and demands for Black racial justice, you can no longer afford to put our institutions' interests above our own humanity. As Black academicians, we have taught our students the importance of holding institutions accountable when our curriculums, pedagogies, policies, and practices do not align with lofty missions of preparing students for global citizenship. Many of us did not design our institutions nor did we create the structures that currently marginalize our students, but we all must play a role in addressing the incongruent and disingenuous academic missions that are misaligned with Black racial justice agendas.

Anti-Blackness exists at all levels of our work and has been well documented in the research literature on Black faculty experiences (Croom \& Patton, 2012; Griffin et al., 2013; Patton \& Catching, 2009; Taylor \& Beatty, 2019; Tuitt et al., 2009). We know that each of you are experiencing the trauma and terror of watching your people slain by 
Journal Committed to Social Change on Race and Ethnicity | Volume 6, Issue 1 | 2020

practitioners of the nation state, better known as the police. We know that you are drained by racial battle fatigue in - by students - and out - by colleagues - of the classroom. We know that even as you attempt to liberate your classroom by way of antiracist and anti-oppressive pedagogies and curriculums, you are still met with resistance from students, administrators, and other faculty. We know that you are dealing with all of this in the midst of a global pandemic that has disproportionately impacted your communities and families. And we know that oftentimes, your non-Black colleagues seem to be tone-deaf to your 400-year-old cries for freedom both inside and outside of academia. Through it all, we know that each of you are dedicated Black educators, committed scholars, and personally exhibit a level of resilience against systematic structured racism. You continue to inspire young people to be innovative, imaginative, authentic, and persistent about social justice and racial equity. In doing so, you must unapologetically center your Blackness. This is not just a time to speak back to antiBlack political agendas, but to also speak up as Black academics who hold a powerful position as knowers and doers in your discipline. Right now, we must do as our sista scholar Dr. Katrina Overby emphatically charged us with in her panelist comments at this year's Summer Institute on Education, Equity, and Justice: "Advocate for change in these streets \& on these sheets" (2020).

\section{Dear Black Staff,}

You matter! We recognize that you are the first responders - academic advisors, student organization advisors, mentors, supervisors, confidants - those who, in this instance, are voluntarily and involuntarily designated to support students through their 
Journal Committed to Social Change on Race and Ethnicity | Volume 6, Issue 1 | 2020

racial trauma. We also recognize that you are first responders for your colleagues. While being a first responder and supporting other Black people through their racial trauma, you are navigating anti-Black racism, questioning of your competence, and experiences of being tokenized (Niemann, 2016). University presidents, administrators, and boards of trustees/regents are often only concerned with politics and the public image of the university. White higher education administrators are causing harm to minoritized people by ignoring and minimizing their experiences (Tevis \& Foste, 2018). This in turn, has required you as Black staff to spend extra time and energy managing harmful environments that have caused additional racial trauma beyond the racial violence embedded throughout society. You have comforted and other mothered Black students and encouraged Black students to press on engaging in their learning and their own well-being (Bailey-Fakhoury, 2017; Collins, 1990). You have done this while your hair has been ridiculed and how you dress, scrutinized. You have done this while codeswitching and accommodating your white colleagues and students and making them feel comfortable with your Blackness. You have done this through being asked to give feedback on diversity statements and leading diversity workshops, while not being compensated for your labor. This labor takes a toll on your emotional, physical, mental, and spiritual well-being. Prioritize your own self-care and self-preservation in order to continue to show up as your best self, so you can continue to support your students in their fight for justice (Quaye et al., 2019).

We know you do this because of your love for your students, your work, and higher education. The academy is only a microcosm of a larger society built, sustained, and embedded in white supremacy. You cannot escape the burden of being Black in 
Journal Committed to Social Change on Race and Ethnicity | Volume 6, Issue 1 | 2020

America because you work in higher education. But still you press on. Continue to press on in all of the beauty and brilliance your Blackness has to offer. But also take a moment to assess if you have the energy and capacity to continue on. Maybe your workplace is too toxic; maybe you do not feel fulfilled; maybe your time in the job has expired and it is time to move on. All of these things are important to reflect on and ask yourself on a regular basis. If it is time to move on, it is ok to do so. Give yourself permission to do so. Feel free to do so. We can only do our best work when we are centering our needs and feel acknowledged, supported, and fulfilled. Find a place where you can do your best work. And most importantly, a place where you also take care of yourself and prioritize your loved ones.

\section{Dear Black Executive Leadership,}

You matter! Unfortunately, the "unexamined historically situated White cultural ideology embedded in the language, cultural practices, traditions, and perceptions of knowledge allow [predominately White institutions] to remain racialized" (Gusa, 2010, p. 465). Thus, we recognize the challenges you, perhaps "a group for whom a future was never imagined" (Cooper, 2016, n.p.), must face when leading in such spaces. As a result, you are a select few; often having to be the 'help' regardless of your rank and title. Not limited to day-to-day tasks, it is during these uncertain times of racial turmoil and civil unrest, that for some of you, your leadership becomes tokenized and laborious, sought after to address the emotional toll racism has had on your campus and/or support the efforts of developing a 'meaningful' response, action plan, and/or lead a task force, that is often incongruent with the institution's culture, climate, or mission. As 
Journal Committed to Social Change on Race and Ethnicity | Volume 6, Issue 1 | 2020

such, your leadership at times may feel performative rather than empowering, which maintains status quo and demonstrates an allegiance to whiteness that only marginally 'protects' your position and worse, reinforces desensitization - a diminished emotional capacity to react to the practices, in this case, of white culture, which inevitably incites racism and anti-blackness (Jones \& Squire, 2018).

Within a context, that more often than not, refuses to name racism as ubiquitous, anti-blackness as pervasive, and whiteness as parasitic, we recognize the challenges you face of being constantly leaned on but cannot lean in - a strategy shrouded in (white) feministic elitism that is void of any critical analysis that acknowledges structural conditions that were never intended to account for you. The insurmountable and disproportionate fallout from the effects of COVID-19 on Black communities, the violent and traumatic deaths of countless Black men, women, and trans* populations at the hands of police (and a new wave of lynching), persistent and enigmatic Black voter suppression, as well as the unsolved conflict of having to convince domestic and foreign societies of Black humanity illustrate what seems to be an insoluble racial climate; one that you are often expected to lead beyond. Some of you carry these injustices to work; being made stronger (or perhaps weakened) by the weight of the burdens of history's past and today's sufferings, while conceivably also becoming desensitized to the idea of a post-racial society. Thus, you are strategic so that you may endure the war against your Black body in order to lead on. We recognize that Black leadership and Black life experiences are not mutually exclusive nor are they a monolith. However, unacknowledged histories compounded by recent events, precipitates a "linked fate" for a number of you - a personal connection to the pain of those who have suffered both 
Journal Committed to Social Change on Race and Ethnicity | Volume 6, Issue 1 | 2020

past and present at the hands of racism (Simien, 2005), that perceivably cannot help but to inform your leadership and impact your practice. With this in mind, as current and former administrators, scholars who study leadership and/or are engaged in a research agenda that is in pursuit of racial justice (Jakakumar \& Adamian, 2015), we offer tangible recommendations to improve the context in which you have elected to lead, with healing in mind.

We encourage you to procure a mentor network (Rockquemore, 2017), and engage with a supportive community, not limited to your institutional context, for your professional trajectory and personal well-being. We recommend that you find white allies - trusted colleagues who have and/or are willing to take up the fight against racial injustice alongside you. Mindful that you are often called on to lead task forces related to and/or serve on committees that are diversity-centered, we encourage you as well as other Leaders of Color, to lead with impunity, calling out white cultural practices (Frankenberg, 1993) to lay bare these unexamined racialized spaces (Gusa, 2010) and begin to rectify racism and oppression (Jones \& Squire, 2018). And because racism and oppression manifests differently across groups, time, and space, it is imperative that you avoid interest convergence (Bell, 1980) - an illumination of how Black racial justice only occurs when it aligns or converges with the interest of white people. Expanding on this premise here, advancing or being inclusive of the interests of othered populations has the potential to dilute any attempts of addressing any one group's specific plight; thus, attempts at Black racial justice become a box checked rather than a strategic resolve. 
Journal Committed to Social Change on Race and Ethnicity | Volume 6, Issue 1 | 2020

We also want to encourage you to learn the art of saying no. We know this is not an easy recommendation. We further recognize that being able to say "no" in the academy is both a privilege and a right, neither of which you may have been afforded. However, taking time before having to decide on an ask, then seeking the support of a mentor or sponsor, who can help you frame your "no", has the potential to be a fruitful exercise. Lastly, and most importantly, we recommend that you take care of yourself in two ways: step away from the need of others to be validated in their ignorance and alleviated of their guilt; and, drawing on the sage advice offered to Black women, be in community with like-minded healthy individuals (Evans et al., 2017).

\section{Dear Black Community,}

You matter and we love you! To our local communities, particularly urban and metropolitan, we acknowledge the very presence of our affiliated institutions and expansive campuses further marginalize your livelihood. We acknowledge members of the local Black community work on our campuses (often in support and non-salaried positions) that help to sustain the operations of the institution. Yet, our institutions largely do not appropriately reciprocate with genuine investment in programs that support Black community health, economic and wealth development (Bell, 2015). We recognize our institutions bring privileged professors and administrators into your communities who sit on school boards and are elected to local offices with attempts to gentrify - and erase - local community and cultural Blackness. Thus, we acknowledge our existence as insular and privileged entities that often occupy spaces in or near your 
Journal Committed to Social Change on Race and Ethnicity | Volume 6, Issue 1 | 2020

communities but do little to specifically, and intentionally, promote economic and financial capital for Black residents of the surrounding communities (Bell, 2015).

To our elected federal, state and local officials, we love you. We recognize the politicized racism and anti-Blackness that you endure pertaining to law and policy making. We have seen the debates and political discourses on Capitol Hill. We acknowledge the work of the Congressional Black Caucus, the collective group of Black senators, governors, mayors, city council members and superintendents. We also acknowledge what you do for Black folks is not always nationally publicized to the same extent as your counterparts, due to underlying media racism and bias.

To our Black centered community and professional organizations that have championed and fought for equality for decades (e.g. NAACP, National Urban League and affiliated chapters, Black Greek Letter Organizations (BGLOs)), we love you. We recognize the fight that you initiated generations ago and continue to inspire generational activism and social mobilization. We continue to look to you for guidance and wisdom pertaining to social action that encourages social change. To BGLOs, we love you and recognize each of your philanthropic initiatives that you have developed and coordinated for decades. As higher education faculty and professionals, we also recognize the role of your organizations in promoting persistence, retention and academic outcomes for Black college students (Hurtado et al., 2015, Quaye et al., 2019). 
Journal Committed to Social Change on Race and Ethnicity | Volume 6, Issue 1 | 2020

\section{Recommendations for Those Who Say They Love Us}

To white leaders we recommend that you, first and foremost, recognize the role your identity plays in your leadership. This level of reflexivity - being self-aware and introspective of what you value, believe, practice, assume, and why - ideally, should result in a cognizant shift within your leadership that enables you to let go of complacency and fragility (white racial anxiety) to be more racially and ethnically inclusive and equitable. Additionally, we recommend that you not only acknowledge race, but also racism, and the ways in which the latter is manifested in institutional policies and practices (Ledesma, 2016; Jones \& Squire, 2018). To do so, you can start by leading through an anti-racist lens (Kendi, 2019; Tevis \& Foste, 2018), critiquing the realities of racism on your campus (Ledesma, 2016; Tevis \& Foste, 2018). We also recommend that you respond to racism, and do so in a way that is substantive (Cole \& Harper, 2017; Jones, 2019; Jones \& Squire, 2018), condemning racism as a whole, not just the individual acts (Tevis \& Foste, 2018). It is also important that your institution's condemnation of racism communicated to the campus writ large be authentic and reflect a shared value of the institutional body as a whole, otherwise such efforts are performative, futile, and at best, maintain status quo (Ahmed, 2012; Ledesma, 2016).

Further, we implore you to begin a review of your campus sources that have the potential to perpetuate oppressive practices such as strategic plans, initiatives, and policies; while also taking a closer look at field-guiding documents such as the Council for the Advancement of Standards in Higher Education (CAS), the Association for American Colleges and Universities (AAC\&U) strategic plan, and free speech legislation. Because higher education's founding is rooted in white supremacy and 
Journal Committed to Social Change on Race and Ethnicity | Volume 6, Issue 1 | 2020

exclusion, then it is perceivable that recommendations may reflect such ideals in subtle ways and incite trauma. Furthermore, be mindful that your recommendation to offer campus workshops, convene and charge a task force, and utilize committees all for diversity and racial justice work should not be shouldered by Black and other Leaders of Color; their labor is spent. Moreover, know these gestures are only going to be as effective as your institutional community's willingness to change. We also strongly encourage postsecondary institutions to take affirmative action (Kennedy, 1961), in this instance, by cognizantly recruiting a diverse pool of colleagues who can address bias practices in real time, rather than in moments of civil unrest. As we think about the tenor of the current socio-political climate, precipitated by police brutality against Black people, we further encourage institutional leaders to be mindful of campus Public Safety and their community partnership with police agencies; as Black and other Communities of Color may be traumatized by an officer's presence or protocol on campus. And we would be remiss in not extending an invitation to non-Black Leaders of Color. You are not exempt from thinking through these actionable recommendations, as well as finding ways to resolve anti-blackness.

As far as supporting Black students, first, support those students who are engaging on campus and becoming active student leaders in the fight for racial justice. How are you ongoingly supporting The Black Lives Matter movement and those participating in the movement on your campus? Encourage Black students in finding a mentor or mentors to support them in their growth and development, both as a scholar and activist. Next, engage with Black collegians in the decision making and governance process when committee and task force work is happening. These committees often 
Journal Committed to Social Change on Race and Ethnicity | Volume 6, Issue 1 | 2020

need student representatives. That representative should not be a token or seat filler, but a fully participating member to offer recommendations and considerations to move the campus forward. Finally, encourage Black students and model for them how to practice self-care - "Caring for myself is not self-indulgence. It is self-preservation, and that is an act of political warfare" (Lorde, 1988, p. 332). This should be your number one priority for Black students. When one takes care of themself, they can then seek to use their agency to help others.

Academic administrators, provosts, deans, unit heads, and program coordinators who care for Black faculty and instructors must contend with how to support those who are on the frontlines. In this moment of racial unrest, it is not enough to ask us "how are we doing?", or to "send your prayers" our way. We need you to materially and discursively show up for us. Putting your body and mind on the line to protest for racial injustice both in and out of academic spaces. Continue to resist and challenge students and colleagues who do not embrace anti-racist movements and ideologies. Additionally, as those who set the academic mission of your institution, the current racial justice imperative ought to be front and center of our undergraduate education initiatives, specifically when designing general education requirements. Courses, both required and elective, on topics of anti-Black racism, intersectionality, racialization in the U.S. and the like, all support the AAC\&U Vision of Educational Excellence Grounded in Equity and Inclusion ${ }^{2}$. Academic administrators should work to establish Truth, Racial Healing \& Transformation (TRHT) Campus Centers ${ }^{3}$. The AAC\&U (2020) suggest that

\footnotetext{
${ }^{2}$ https://www.aacu.org/press/press-releases/association-american-colleges-and-universities-releasesnew-guiding-vision

${ }^{3}$ https://www.aacu.org/trht-campus-centers
} 
Journal Committed to Social Change on Race and Ethnicity | Volume 6, Issue 1 | 2020

these spaces operate to prepare the next generation of strategic leaders and thinkers to break down racial hierarchies and dismantle the belief in the hierarchy of human value. If academic affairs divisions are committed to equity, inclusion, and social justice, creating spaces and curriculums that address racial realities and intervene in racial healing is a strong form of racial advocacy.

Higher education administrators must start centering the experiences of Black staff. Administrations can do this by intentionally considering the role of affinity groups (i.e., Black Faculty and Staff Networks) in offering support and agency for Black staff across campuses. Administrations should also offer their support financially for these affinity groups to build community and support amongst one another. Black staff should also be compensated for their ongoing labor when supporting Black students and addressing racism on campus. Black staff navigate racial battle fatigue on an ongoing basis. Administrators can support those navigating racial battle fatigue by acknowledging this type of fatigue exists and impacts Black staff's mental and physical health. Additionally, Black staff need to be supported by acknowledging their unique contributions and not tokenizing them and their work. White hiring managers and search committee members can also support Black staff by interrogating the concept of "fit" and addressing their own conscious and unconscious racial biases (Tevis, 2020).

To our elected officials, we support you and encourage you to continue to fight for anti-racism in politics and policymaking. We encourage you to partner with the higher education academic community to draft education related legislation that strives to disrupt institutionalized and structural racism in every aspect of present-day colleges and universities (Jayakumar \& Adamian, 2015). It is well known that the student debt 
Journal Committed to Social Change on Race and Ethnicity | Volume 6, Issue 1 | 2020

crisis continues to be a critical matter for Black college students (EdTrust, 2020). We encourage you to continue to seek solutions for policies that continue to disproportionately affect Black students. To our community and professional associations, we stand with you in the fight for social justice. We urge you to develop additional means for Black college student activism and mobilization. We also encourage you to tackle the most pressing critical matters for Black students that have arguably received insufficient attention by the larger Black community, such as mental health, homophobia and LGBTQ equality, spiritual diversity, (dis)ability and ableism that continue to affect Black college students.

\section{As We Continue to Press On}

As higher education continues to reckon with addressing anti-Black racism and moving towards sustainable racial justice frameworks, JCSCORE will continue to publish and highlight work that centers the full humanity of Black people in higher education (Chang, 2015); as we should have our full humanity recognized and respected. Diversity and inclusion statements, task forces, and diversity trainings are not the ending point when addressing anti-Blackness in higher education. The work of eradicating racists policies and practices rooted in anti-Black ideology must be ongoing. To our Black colleagues and students, we hope you feel that you matter daily and your lived experiences are honored and centered as we press on towards racial reckoning and full liberation. 
Journal Committed to Social Change on Race and Ethnicity | Volume 6, Issue 1 | 2020

\section{References}

Association of American Colleges and Universities. (2020). Truth, racial healing, and transformation (TRHT) campus centers. https://www.aacu.org/trht-campuscenters

Acker, L. D., (2017). Faces in the crowd: A narrative inquiry into the relationship violence experienced by four Black college women. Graduate Theses and Dissertations. https://lib.dr.iastate.edu/etd/16910

Ahmed, S. (2012). On being included: Racism and diversity in institutional life. Duke University Press.

Brady, S. T., Cohen, G. L., Jarvis, S. N., \& Walton, G. M. (2020). A brief socialbelonging intervention in college improves adult outcomes for Black Americans. Science Advances, 6(18), eaay3689. DOI: 10.1126/sciadv.aay3689

Bailey-Fakhoury, C. (2017) Learning through collective testimony: African American motherwork, Womanism, and praxis. Journal of the Motherhood Initiative, 8(1-2), 167-182.

Bell Jr, D. A. (1980). Brown v. Board of Education and the interest-convergence dilemma. Harvard law review, 93,(3), 518-533. DOI: 10.2307/1340546

Bell, D. (2015). Is American racism economics by another name? Journal Committed to Social Change on Race and Ethnicity, 1(2), 4-22. https://doi.org/10.15763/issn.2642-2387.2015.1.2.4-23

Chang, M. (2015). Applying our imagination to settle unfinished business. Journal Committed to Social Change on Race and Ethnicity, 1(1), 4-20. https://doi.org/10.15763/issn.2642-2387.2015.1.1.4-20

Cole, E. R., \& Harper, S. R. (2017). Race and rhetoric: An analysis of college presidents' statements on campus racial incidents. Journal of Diversity in Higher Education, 10(4), 318-333.

Collins, P. H. (1986). Learning from the outsider within: The sociological significance of Black feminist thought. Social Problems, 33(6), S14-S32.

Collins, P. H. (1990). Black feminist thought. Routledge.

Cooper, B. (2016). The racial politics of time. TedWomen. https://www.ted.com/talks/brittney_cooper_the_racial_politics_of_time?language $=$ en

Croom, N., \& Patton, L. (2012). The miner's canary: A critical race perspective on the representation of Black women full professors. Negro Educational Review, 62(14), 13-39.

Douglas, T. M., Toldson, I., Shockley, K. G., \& Banks, J. A. (2020). Campus uprisings: How student activists and collegiate leaders resist racism and create hope. Multicultural Education.

EdTrust, 2020. Black Student Debt: Explaining the Crisis and Providing Solutions. https://edtrust.org/black-student-debt/

Evans, S. Y., Bell, K., \& Burton, N. K. (2017). Black women's mental health: balancing strength and vulnerability. SUNY Press.

Frankenberg, R. (1993). White women, race matters: The social construction of whiteness. University of Minnesota Press. 
Journal Committed to Social Change on Race and Ethnicity | Volume 6, Issue 1 | 2020

Grady, C. (2020, June 30). Why the term "BIPOC" is so complicated, explained by linguists. Vox. https://www.vox.com/2020/6/30/21300294/bipoc-what-does-itmean-critical-race-linguistics-jonathan-rosa-deandra-miles-hercules

Griffin, K. A., Bennett, J. C., \& Harris, J. (2013). Marginalizing merit?: Gender differences in Black faculty $\mathrm{D} /$ discourses on tenure, advancement, and professional success. The Review of Higher Education, 36(4), 489-512.

Gusa, D. L. (2010). White institutional presence: The impact of Whiteness on campus climate. Harvard Educational Review, 80(4), 464-490.

Hurtado, S., Ruiz Alvarado, A., Guillermo-Wann, C. (2015). Creating inclusive environments: The mediating effect of faculty and staff validation on the relationship of discrimination/bias to students' sense of belonging. Journal Committed to Social Change on Race and Ethnicity, 1(1), 59-81. https://doi.org/10.15763/issn.2642-2387.2015.1.1.59-81

Jayakumar, U. M. \& Adamian, A. S. (2015). Toward a critical race praxis for educational research: Lessons from affirmative action and social science advocacy. Journal Committed to Social Change on Race and Ethnicity, 1(1), 21-58. https://doi.org/10.15763/issn.2642-2387.2015.1.1.21-58

Jones, V. (2019). Discourse within University Presidents' Responses to Racism: RevealingPatterns of Power and Privilege. Teachers College Record, 121(6), n6. Jones, V. A \& Reddick, R. J. (2017). The Heterogeneity of Resistance: How Black Students Utilize Engagement and Activism to Challenge PWI Inequalities. The Journal of Negro Education, 86(3), 204-219.

Jones, V. A. \& Squire, D. (2018). Disengaging whiteness and examining power in campus activism: Reuniting communities of color through a critical race analysis of tempered radicalism. Journal Committed to Social Change on Race and Ethnicity, 4(1), 36-65. https://doi.org/10.15763/issn.2642-2387.2018.4.1.36-65

Quaye, S. J., Karikari, S. N., Allen, C. R., Okello, W. K., \& Carter, K. D. (2019). Strategies for practicing self-care from racial battle fatigue. Journal Committed to Social Change on Race and Ethnicity, 5(2), 94-131. https://doi.org/10.15763/issn.2642-2387.2019.5.2.94-131

Kendi, I. X. (2019). How to be an antiracist. One world.

Kennedy, J. F. (1961). Executive Order 10925. Establishing the President's Committee on Equal Employment Opportunity. Fed Reg, 26, 1977. https://www.presidency.ucsb.edu/documents/executive-order-10925establishing-the-presidents-committee-equal-employment-opportunity

Kuh, G. D., \& Love, P. G. (2000). A cultural perspective on student departure. In Braxton, J. (Ed.), Reworking the student departure puzzle: New theory and research on college student retention (pp. 196-212). Vanderbilt University Press.

Ledesma, M. C. (2016). Complicating the binary: Towards a discussion of campus climate health. Journal Committed to Social Change on Race and Ethnicity, 2(1), 5-35. https://doi.org/10.15763/issn.2642-2387.2016.2.1.5-35

Lorde, A. (1988). A burst of light: Essays. Firebrand Books.

Linder, C., Quaye, S.J., Lange, A.C., Roberts, R.E., Lacy, M.C., \& Okello, W.K. (2019). "A Student Should Have the Privilege of Just Being a Student": Student Activism as Labor. The Review of Higher Education, 42(5), 37-62. 
Journal Committed to Social Change on Race and Ethnicity | Volume 6, Issue 1 | 2020

Niemann, Y. F. (2016). The social ecology of tokenism in higher education. Peace Review, 28(4), 451-458, DOI: 10.1080/10402659.2016.1237098

Overby, K. (2020, June 23). Black woman and girls in higher education. Social Justice in Higher Education [Panel presentation]. Summer institute on education, equity, and justice: uplifting Black women \& girls of color through antiracist pedagogy, practice, \& policy. Summer Institute on Education and Justice Virtual Conference. https://youtu.be/7mKwgr-EgXU

Patton, L. D. (2018). Dr. Lori Patton Davis 2018 ASHE Conference Keynote Address. Presidential Address presented at the Association for the Study of Higher Education, Tampa, FL.

Patton, L. D., \& Catching, C. (2009). Teaching while Black: Narratives of African American student affairs faculty. International Journal of Qualitative Studies in Education, 22(6), 713-728.

Simien, E. M. (2005). Race, gender, and linked fate. Journal of Black Studies, 35(5), 529-550.

Stewart, D-L. (2019). Ideologies of absence: Anti-Blackness and inclusion rhetoric in student affairs practice. Journal of Student Affairs, 28, 15-30.

Stewart, D-L. (2020). Workout/Through. College Student Educators International [Blog post]. https://www.myacpa.org/blogs/black-lives-matter-blog/working-outthrough

Strayhorn, T. (2012). College students' sense of belonging: A key to educational success for all. Routledge.

Taylor, L., \& Beatty, C. (2018). Toward a liberatory praxis for new Black faculty. In R. Jeffries (Ed.) (Ed.), Diversity, Equity, and Inclusivity in Contemporary Higher Education (pp. 108-121). IGI Global Publishing.

Tevis, T. (2020) Exploring how White male postsecondary presidents respond to racism. Whiteness and Education, 5(1), 91-111. https://doi.org/10.1080/23793406.2019.1711150

Tevis, T. \& Foste, Z. (2018, November). From Complacency to Criticality: Envisioning Anti-Racist Leadership Among White Higher Education Administrators. Association for the Study of Higher Education.

Tuitt, F., Hanna, M., Martinez, L. M., Salazar, M. C., \& Griffin, R. (2009). Teaching in the line of fire: Faculty of color in the academy. The NEA Higher Education Journal, 65-74. http://www.nea.org/assets/docs/HE/TA09LineofFire.pdf

Vaccaro, A., \& Mena, J. A. (2011). It's not burnout, it's more: Queer college activists of color and mental health. Journal of Gay \& Lesbian Mental Health, 15(4), 339367. 